\title{
Free Thyroxine in Human Serum: Simplified Measurement with the Aid of Magnesium Precipitation*
}

\author{
Kenneth Sterling $†$ And Milton A. Brenner \\ (From the Medical Service, Bronx Veterans Administration Hospital, Bronx, N. Y.)
}

The measurement of free thyroxine concentration by dialysis of ${ }^{131}$ I-labeled thyroxine from serum, followed by fractionation of the dialyzate in a resin column, was described in a previous report from this laboratory (1). Metabolic status was found to be closely correlated with the concentration of unbound hormone (1). The major technical problem in such a determination has been the freeing of the dialyzate of contaminating radioactive iodide, which inevitably far exceeds the thyroxine radioactivity in the fluid. The exacting nature of the column fractionation prompted the effort to design an abbreviated procedure for this purpose. The methods we investigated have included the use of diluted serum to increase dialyzable thyroxine, the addition of carrier protein to dialyzates for trichloroacetic acid precipitation, and the employment of gel filtration of dialyzates or of whole serum. All of these have presented various technical disadvantages. Of the methods explored, precipitation of thyroxine by magnesium offered maximal simplicity.

In his original descriptions of various metal salts of thyroxine, Kendall $(2,3)$ mentioned the extreme insolubility of magnesium salts of the hormone. The interaction between magnesium and thyroxine was described briefly by Lardy (4) as the formation of a chelate in which three molecules of thyroxine combine with one magnesium ion at $\mathrm{pH} 8.5$ to 9.0. The solubility product of the chelate was given as $10^{-17}$.

The method of magnesium precipitation after addition of carrier thyroxine to dialyzates provided

\footnotetext{
* Submitted for publication January 25, 1965 ; accepted October 15, 1965.

Supported in part by grants AM-02770-06 and -07 from the U. S. Public Health Service and grant P-226 from the American Cancer Society to the Research Foundation for Mental Hygiene.

$\dagger$ Address requests for reprints to Dr. Kenneth Sterling, Veterans Administration Hospital, 130 West Kingsbridge Rd., Bronx, N. Y. 10468.
}

a simple and reproducible procedure for the routine determination of free thyroxine, which will be described in detail in this paper.

\section{Methods}

\section{Materials}

L-Thyroxine- ${ }^{131} \mathrm{I}$ in propylene glycol solution with $0.2 \%$ cysteine added for stabilization was obtained from a commercial source. ${ }^{1}$ A specific activity of at least $36 \mathrm{mc}$ per mg was required for optimal counting rates. This could be obtained by requesting it from the supplier. Shipments were tested for purity by descending paper chromatography as previously described $(5,6)$ and were discarded if found to be less than $95 \%$ pure. The labeled thyroxine was free of radioactive contaminants other than 1 to $5 \%$ iodide. The precise per cent of radioactivity due to iodide- ${ }^{131} \mathrm{I}$ was determined by paper electrophoresis in a glycine acetate system (7) for 90 minutes; quadruplicate strips yielded close agreement. The thyroxine- ${ }^{131} \mathrm{I}$ was diluted $1: 25$ in $0.125 \mathrm{~g}$ per $100 \mathrm{ml}$ albumin solution and stored at $4^{\circ} \mathrm{C}$. Little or no decomposition was observed over a 2-week period. Shipments were usually depleted within 10 days. The folowing chemicals were purchased: nonradioactive $\mathrm{L}$-thyroxine ${ }^{2}$; magnesium chloride $\left(\mathrm{MgCl}_{2}\right.$. $6 \mathrm{H}_{2} \mathrm{O}$ ), certified reagent grade ${ }^{3}$; and Tris [tris (hydroxymethyl) aminomethane].4 Colorless Merthiolate powder was kindly provided. 5

Dialysis bags were made from Visking precision Nojax cellulose casing (30/32 inch), which was more durable, as well as a more convenient size than "dialysis tubing" $(27 / 32$ inch). The cellulose casing in rolls of 100 feet was purchased directly from the manufacturer. ${ }^{6}$ Cellulose nitrate tubes $(28 \times 102 \mathrm{~mm})$ with $50-\mathrm{ml}$ capacity were purchased. ${ }^{7}$

All blood sera not used the day they were drawn were stored frozen. Repeated freezing and thawing had no evident effect upon the results. Large pools of sera 8 were run as standards with each set of dialysis experiments.

1 Abbott Laboratories, North Chicago, Ill.

2 Mann Research Laboratories, New York, N. Y.

${ }^{3}$ Fisher Scientific Co., New York, N. Y.

4 Sigma Chemical Co., St. Louis, Mo.

5 Lilly Research Laboratories, Indianapolis, Ind.

6 Union Carbide Corp., Visking Division, Chicago, Ill.

7 Ivan Sorvall, Inc., Norwalk, Conn.

8 Supplied by the clinical chemistry laboratory, Veterans Administration Hospital, Bronx, N. Y. 


\section{Clinical material}

Thyrotoxicosis. Thirty-three hyperthyroid patients were available from the Veterans Administration Hospital and its Radioisotope Service, the Thyroid Clinic, and the Radiotherapy Department of the Presbyterian Hospital. The diagnoses were verified by thyroidal uptake of ${ }^{181} \mathrm{I}$, as well as thyroidal clearance (8) in the patients from the Veterans Administration Hospital Radioisotope Service. In most instances a protein-bound iodine (PBI) determination was also available.

Normal. Blood sera were obtained from 21 physicians and laboratory workers without apparent disease.

Hypothyroidism. Fourteen hypothyroid subjects were available from the same sources as the patients with thyrotoxicosis. The diagnoses were verified by thyroidal uptake, PBI, and usually by other tests as well. Two patients had hypothyroidism after thyroidectomy; five were hypothyroid after ${ }^{181} \mathrm{I}$ therapy; one patient had hypopituitarism; four represented classical spontaneous idiopathic myxedema. One patient had a diffuse goiter associated with myxedema; the goiter disappeared after adequate desiccated thyroid therapy was instituted. One subject had pronounced hypothyroidism several months after an episode of acute thyroiditis accompanied by mild thyrotoxicosis.

Pregnancy. Blood sera were obtained from 37 women beyond the first trimester of normal pregnancy, in the Obstetrical Clinic of the Presbyterian Hospital.

Euthyroid "sick" group. Blood samples were obtained from a group of 19 patients with various diseases but with no significant thyroid disorder. The illnesses included hepatic cirrhosis and other diseases of the liver, metastatic carcinoma, and renal insufficiency. The patients were all seriously ill, in some instances moribund.

\section{Stock solutions}

All solutions were made with deionized water. The following were used: Tris solution, 0.2 mole per $\mathrm{L}, \mathrm{pH}$ 10.6 to 10.7 ; Tris-sodium chloride solution, $0.05 \mathrm{M}$ Tris to

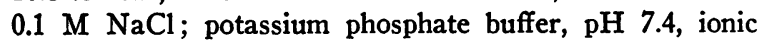
strength 0.15 . To the phosphate buffer was added onehundredth vol of $1 \%$ Merthiolate solution yielding a final concentration of $1: 10,000$ Merthiolate for bacteriostasis.

Also employed were: nonradioactive thyroxine solution, $1 \mathrm{mg}$ per $\mathrm{ml}$ in $0.033 \mathrm{~N} \mathrm{NaOH}$, stored in a brown plastic bottle at $4^{\circ} \mathrm{C}$; magnesium chloride $\left(\mathrm{MgCl}_{2} \cdot 6 \mathrm{H}_{2} \mathrm{O}\right)$ solution, $40 \%$ (wt/vol) ; magnesium chloride $\left(\mathrm{MgCl}_{2} \cdot 6 \mathrm{H}_{2} \mathrm{O}\right.$ ) precipitating solution, $10 \% \mathrm{MgCl}_{2} \cdot 6 \mathrm{H}_{2} \mathrm{O}$ in Tris-sodium chloride, $\mathrm{pH}$ 9.3. Dilution of the stock $40 \% \mathrm{MgCl}_{2}$. $6 \mathrm{H}_{2} \mathrm{O}$ solution in the Tris- $\mathrm{NaCl}$ solution resulted in $\mathrm{pH}$ 9.3 without titration. Magnesium chloride $\left(\mathrm{MgCl}_{2}\right.$. $6 \mathrm{H}_{2} \mathrm{O}$ ) wash solution was the same as the above, except that it was titrated to $\mathrm{pH} 8.7$ to 8.8 with hydrochloric acid.

\section{Methods}

The general procedure employed was similar to that described previously $(1,5,6,9)$. The dialysis membranes were specially cleaned by soaking them in $0.1 \mathrm{M}$ nitric acid for 16 to 24 hours, and then for 1 to 3 days in 0.01 $M$ nitric acid, followed by storage in deionized water at $4^{\circ}$ C. Before use, the dialysis bags were washed repeatedly with deionized water. The moist bags were sealed at one end by a square knot, tested with water to exclude leaks, inflated, and a marble inserted before drying. The marble served to keep the dialysis tubing open to facilitate the introduction of serum with a pipette. During dialysis the presence of the marble within the bag insured optimal mixing. The bags were usually dried at room temperature for six hours or more, but air from a hair dryer was occasionally used to accelerate the drying process. In later studies it was found possible to minimize the occasional occurrence of pinholes in completely dry bags by allowing them to remain slightly moist and storing them, with marbles inserted, in a desiccator containing a vial of water, as recommended by Walser (10). Dialysis was carried out as previously described (1) in 50-ml plastic (cellulose nitrate) centrifuge tubes, which minimized adsorption of thyroxine from dilute solution. After the addition of $3 \mathrm{ml}$ of serum containing a "tracer" amount (cf. below) of radioactive thyroxine inside the bag, $5 \mathrm{ml}$ of phosphate buffer was added to the outside.

The dialysis was carried out for approximately 16 hours at $37^{\circ} \mathrm{C}$ in a water bath shaker ${ }^{9}$ run at a rate of 130 horizontal strokes per minute. The 16-hour interval was selected to provide almost complete equilibration as well as maximal convenience from the standpoint of the laboratory schedule.

In control tubes with no protein inside the bag, radioactivity was essentially the same in both compartments with 16 hours of shaking at $37^{\circ} \mathrm{C}$. The recoveries of radioactivity ranged from 95 to $97 \%$, indicating the absence of appreciable binding by dialysis bags or the walls of the plastic tubes.

The dialyzate was crystal clear in the usual 16-hour runs as well as for longer periods of equilibration, such as 48 or 72 hours, with $1: 10,000$ Merthiolate in the buffer. The use of $1: 50,000$ instead of the regular $1: 10,000$ final concentration of Merthiolate in the buffer resulted in inadequate bacteriostasis and occasional cloudy dialyzates due to bacterial growth. The use of $1: 500$ Merthiolate concentration resulted in appreciably increased values of free thyroxine, presumably due to displacement of the hormone from serum protein-binding sites. Ultrafiltration studies were carried out with and without Merthiolate in the regular concentration range for dialysis $(1: 10,000)$. The results showed no measurable displacement of thyroxine under these circumstances. Dialysis studies with and without $1: 10,000$ Merthiolate in the buffer revealed no systematic differences. In tubes lacking the bacteriostatic agent, however, the amount of cloudiness due to bacterial contamination was quite variable. The occurrence of wider variation between replicate dialyses was considered related to bacterial growth and led to the decision to employ Merthiolate regularly. It was later found that tetracycline $(2.3 \mathrm{mg}$ per $100 \mathrm{ml})$

${ }^{9}$ Model 2156, Research Specialties Co., Richmond, Calif. 
provided equal or superior bacteriostasis without detectable displacement of thyroxine.

From the clear dialyzate, $3 \mathrm{ml}$ was pipetted into a screw-cap counting tube to which was then added $2 \mathrm{ml}$ of the $1 \mathrm{mg}$ per $\mathrm{ml}$ carrier thyroxine solution. The tube was briefly mixed with a Vortex mixer. Upon addition of $1 \mathrm{ml}$ of the magnesium chloride precipitating solution, a dense white precipitate was seen immediately. The tube was again agitated with a Vortex mixer. After initial centrifugation and decantation of the clear supernatant solution, the precipitate was washed three times with $5 \mathrm{ml}$ of the magnesium chloride wash solution; the Vortex mixer was employed to achieve thorough washing. After the final centrifugation, the washed precipitate occupied a volume of approximately $1.0 \mathrm{ml}$. The radioactivity of the precipitate was assayed in a Packard AutoGamma well-type scintillation counter and was compared with a $1.0-\mathrm{ml}$ standard of the original serum before dialysis. This standard was usually made from $0.5 \mathrm{ml}$ of the original serum plus $0.5 \mathrm{ml}$ saline solution. The per cent free thyroxine represented the quotient of the radioactivity in the precipitate divided by the radioactivity in the original serum, corrected by subtraction of iodide radioactivity. Since the precipitate represented all thyroxine in $3 \mathrm{ml}$ of dialyzate, it was compared with the thyroxine radioactivity of $3 \mathrm{ml}$ of serum. The reproducibility of the procedure may be judged by nine consecutive determinations on a serum pool that yielded a coefficient of variance of $5 \%$. Nine determinations on the same day gave a coefficient of variance of $3 \%$.

The method described above for freeing the thyroxine in the dialyzate of contaminating iodide was tested by employing dialyzates of nonradioactive serum to which were added either iodide- ${ }^{131} \mathrm{I}$ or radioactive thyroxine. After three washings, the magnesium-thyroxine precipitates were found to contain less than $0.1 \%$ of iodide- ${ }^{121} \mathrm{I}$ radioactivity added; the recovery of added thyroxine was almost quantitative, in all instances greater than $95 \%$.

For purposes of comparison, another $3 \mathrm{ml}$ of the dialyzate was used to determine the free thyroxine by the "resin dialysis" method of Ingbar, Braverman, Dawber, and Lee (11-13).10 Samples of the same dialyzates run by both methods were in agreement for normal and abnormal sera. In such studies, $5 \mathrm{ml}$ of serum was dialyzed against $8 \mathrm{ml}$ of buffer.

In most instances there was sufficient serum available to permit determination of $\mathrm{PBI} 11$ or thyroxine iodine or both by column 12 in addition to the dialysis.

Ultrafiltration studies were considered necessary to establish that the period of mixing in the water bath shaker had achieved or closely approached equilibrium. This question assumed particular importance in view of the observation of variable but always higher values

10 The details of this procedure were kindly made available by Dr. Ingbar before publication of the complete description.

11 J. R. Leonards Medical Laboratory, Cleveland, Ohio, or Bio-Science Laboratories, Los Angeles, Calif.

12 Bio-Science Laboratories. when the tracer was added to the buffer outside the bag rather than to the serum in the bag (1).

Unpublished data (14) afforded general confirmation with Toribara tubes ${ }^{13}$ (15), and also with the Araflo ${ }^{14}$ method of ultrafiltration. In the present work, a somewhat more convenient method of ultrafiltration was employed (16). The radioactive serum was placed in the $30 / 32$ inch cellulose casing in the form of a "U-tube" rather than a knotted bag. The bag was suspended by being tightly stoppered, with the ends of the cellulose casing protruding above the stopper, in a cellulose nitrate tube. A small clinical centrifuge 15 within an incubator was used to spin four such tubes simultaneously. With 4 $\mathrm{ml}$ of serum in each of four tubes, it was possible to obtain $3 \mathrm{ml}$ of clear ultrafiltrate from the four tubes in 3 hours of centrifugation at the maximal speed equivalent to about $800 \mathrm{~g}$.

With occasional adjustment of the ventilation of the incubator to compensate for the heat produced by the centrifuge, it was possible to maintain the temperature close to $37^{\circ} \mathrm{C}\left(35\right.$ to $\left.38^{\circ} \mathrm{C}\right)$ during the centrifugation. As shown below, the free thyroxine values obtained by ultrafiltration of serum afforded confirmation of the dialysis method.

\section{Results}

Rate of equilibration in the dialysis system. The adequacy of a 16-hour period for the achievement of dialysis equilibrium is illustrated in Figure 1, which is typical of the results of several kinetic studies.

The close correspondence between the values of the magnesium precipitation and resin dialysis (11-13) procedures may be seen in Figure 1.

When thyroxine was added to the buffer outside the bag, the approach to equilibrium was slower. As previously observed in equilibrium dialysis studies with human serum albumin (5), EDTA was required to achieve approximate equilibrium when tracer was added to the buffer, presumably because of the presence of trace metals even in deionized water. Without EDTA, a wide scatter of points was obtained (5), and even in its presence, it was only occasionally possible to obtain better equilibration than is illustrated in Figure 1 when the tracer was added to the protein-free buffer fluid [cf. (1) and Methods].

On the other hand, adding the tracer to the solution of serum within the bag invariably gave values

13 Toribara ultrafiltration chamber, no. 13000 , Will Corporation, Bronx, N. Y.

14 Araflo ultrafiltration apparatus, Applied Research Associates, New York, N. Y.

15 Model $\mathrm{H}$, no. 417, International Equipment Company, Boston, Mass. 


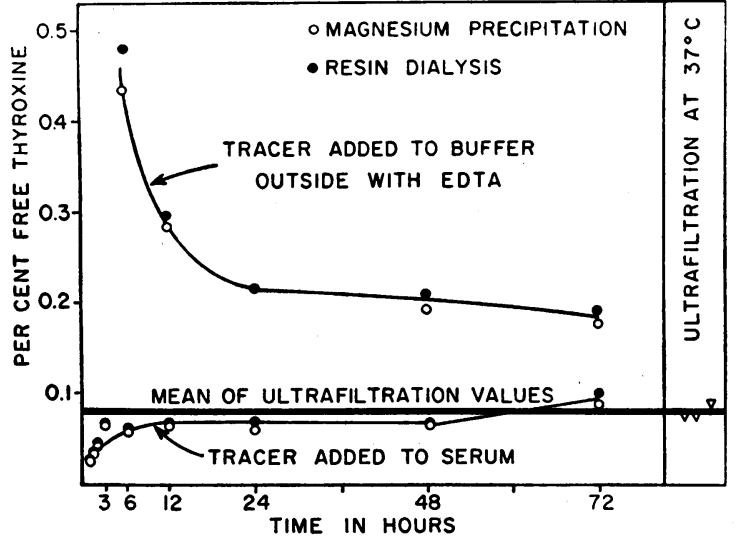

Fig. 1. Rate of equilibration IN dialysis System.

in close agreement with those of ultrafiltration, which were regarded as a standard not dependent upon any equilibration time. The presence or absence of EDTA in the buffer made no difference when tracer was added to the serum within the bag.

Comparative studies were carried out with the serum outside the dialysis bag and the buffer solution inside. The close correspondence of the results with those of the regular procedure supported the absence of significant interference from adsorption of thyroxine by the walls of the cellulose nitrate tubes.

The "tracer" amount of thyroxine and the effect of enrichment with nonradioactive thyroxine. To portions of a serum pool with a PBI concentration of $4.7 \mu \mathrm{g}$ per $100 \mathrm{ml}$ were added successively greater amounts of nonradioactive thyroxine. The increasing values of the free thyroxine fraction indicated displacement of progressively greater amounts of hormone (Figure 2). In a series of such experiments, slight but definite increases were observed with additions of "cold" carrier, which raised the concentration of thyroxine by as little as 5 to $8 \mu \mathrm{g}$ per $100 \mathrm{ml}$.

In light of these effects by rather small increments of hormone concentration, studies were undertaken regarding the "tracer" level. To portions of a serum pool with PBI concentration of $4.7 \mu \mathrm{g}$ per $100 \mathrm{ml}$ were added successive dilutions of a fresh shipment of thyroxine-131I of high specific activity. The results, shown in Table I, revealed no systematic differences. Therefore, changes in the amount of carrier in this range had no measur-

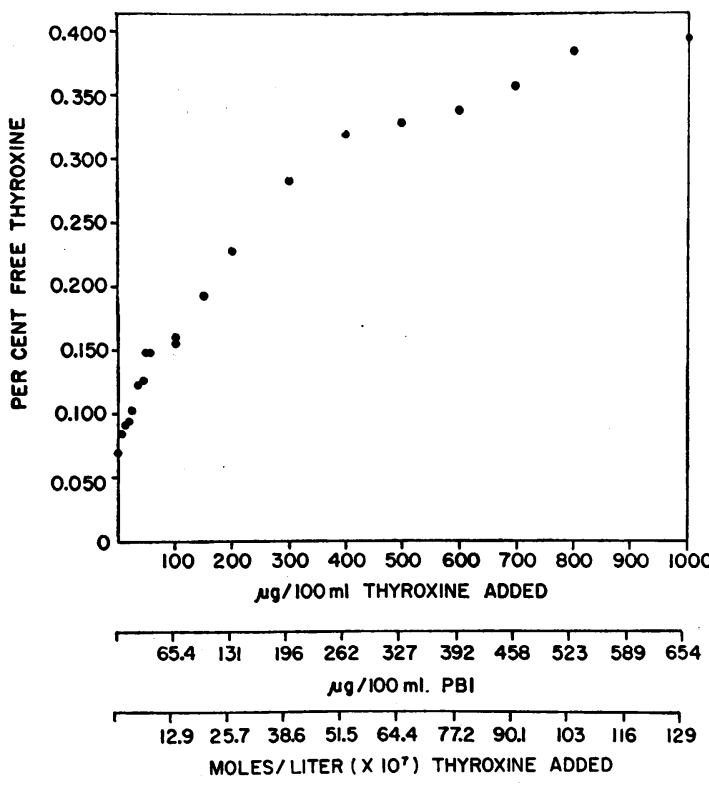

Fig. 2. EFFECT OF LOADING UPON PER CENT FREE THYROXINE IN SERUM. The thyroxine added is expressed as $\mu \mathrm{g}$ per $100 \mathrm{ml}$, as protein-bound iodine (PBI) increment, and also as moles per liter $\times 10^{7}$.

able effect upon the per cent free thyroxine. The values were likewise unaltered when similar studies were carried out with sera of myxedematous subjects. The results of several such experiments indicated that a thyroxine increment of $3 \mu \mathrm{g}$ per $100 \mathrm{ml}$, corresponding to a PBI increment of $2 \mu \mathrm{g}$ per $100 \mathrm{ml}$, was within the tracer range for human serum. In such studies the thyroxine concentrations given by the supplier were verified by independent PBI determinations. It was therefore

TABLE I

The effect of addition of successively diminishing amounts of thyroxine-131I to a serum pool

\begin{tabular}{ccc}
\hline \hline $\begin{array}{c}\text { Added } \\
\text { thyroxine }\end{array}$ & $\begin{array}{c}\text { Computed PBI } \\
\text { increment* }\end{array}$ & $\begin{array}{c}\text { Free } \\
\text { thyroxine }\end{array}$ \\
\hline$\mu g$ per & $\mu g$ per $100 \mathrm{ml}$ & $\%$ \\
$100 \mathrm{ml}$ & 1.73 & 0.060 \\
2.64 & 0.86 & 0.068 \\
1.32 & 0.58 & 0.063 \\
0.88 & 0.43 & 0.060 \\
0.66 & 0.29 & 0.061 \\
0.44 & 0.22 & 0.071 \\
0.33 & Mean value & 0.064 \\
&
\end{tabular}

* The computed protein-bound iodine (PBI) increment is obtained by multiplying the amount of added thyroxine by $\mathbf{0 . 6 5 4}$, the proportion of iodine in the molecular weight of thyroxine. 


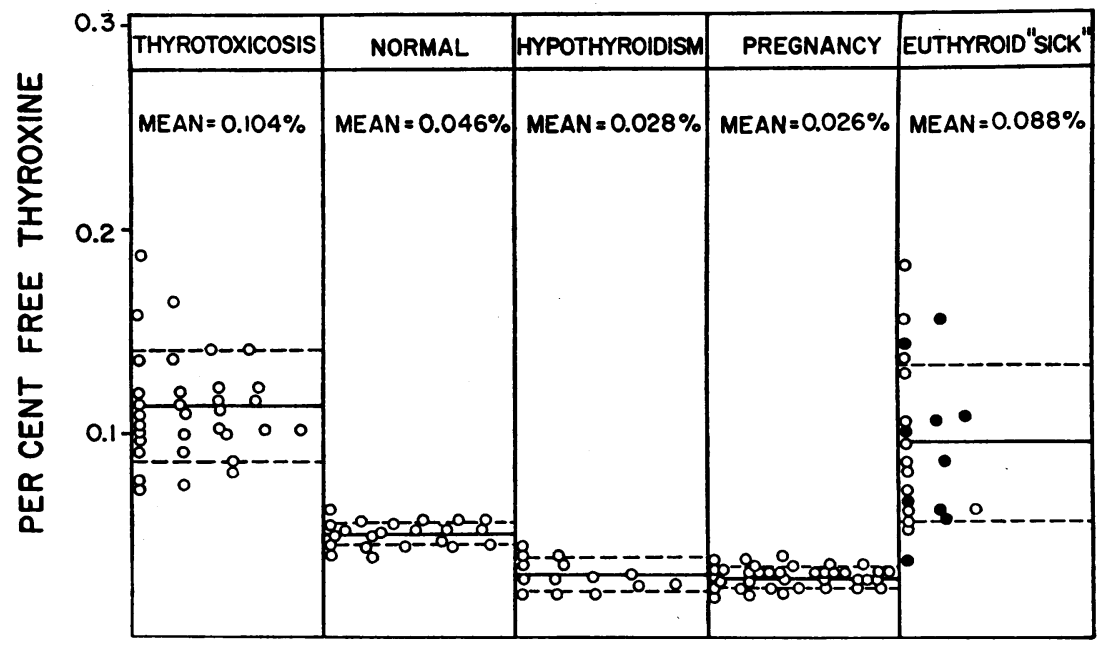

Fig. 3. Free thy AND DISEASE. Mean values are indicated by horizontal solid lines and standard deviations by broken lines. Filled circles represent patients with liver disease.

inferred that addition to a given serum of a thyroxine increment of $3 \mu \mathrm{g}$ per $100 \mathrm{ml}$ or less should have no detectable effect upon the free thyroxine fraction of that particular serum.

Free thyroxine concentration in health and disease. The results of the determinations of per cent free thyroxine are illustrated in Figure 3 . The mean value obtained in thyrotoxicosis was more than twice the normal mean. In hypothyroidism and in pregnancy the values were slightly more than half the normal mean. The elevated results in the euthyroid "sick" group showed great variations.

The product of the per cent free thyroxine and the PBI represents the free thyroxine iodine concentration. As illustrated in Figure 4, the mean normal value was $2.76 \mathrm{~m} \mu \mathrm{g}$ per $100 \mathrm{ml}$. The mean free thyroxine iodine in thyrotoxicosis was more than four times the normal, and the mean in hypothyroidism was less than one-seventh the normal. In pregnancy the values were quite close to the normal range, since they were the products of a

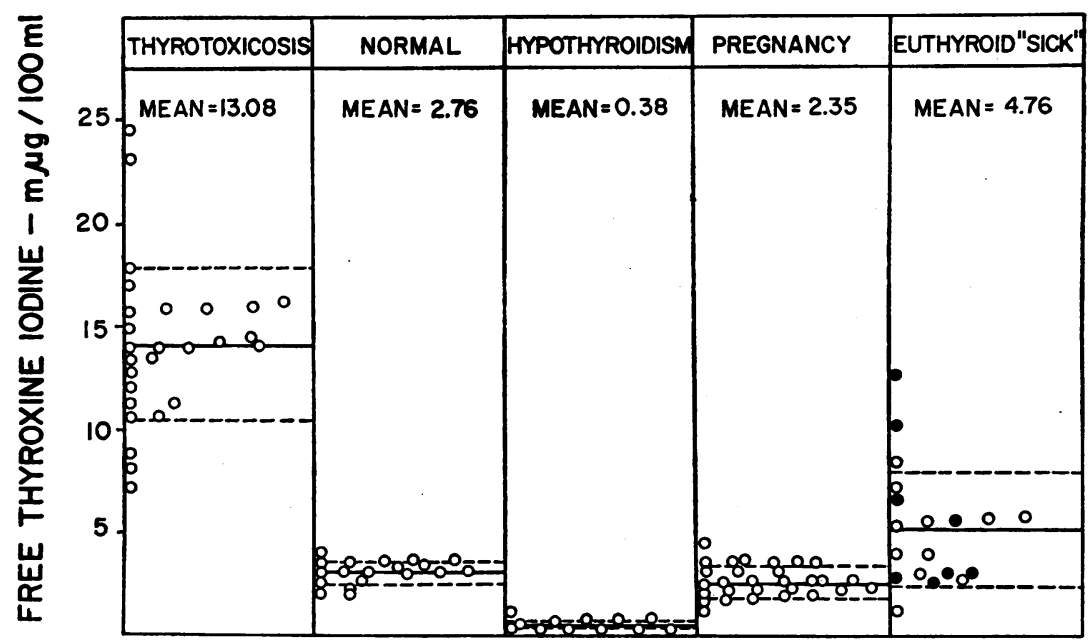

Fig. 4. Free thyoxine iodine in SERUM IN health aNd DISEASE. The points represent the products of the free thyroxine percentages and the PBI or thyroxine iodine values. Mean values are indicated by horizontal solid lines and standard deviations by broken lines. Filled circles represent patients with liver disease. 
TABLE II

Free thyroxine in normal and pathological sera*

\begin{tabular}{lccc}
\hline \multicolumn{1}{c}{ Sera } & $\%$ & $\begin{array}{c}\text { Free } \\
\text { Free } \\
\text { thyroxine }\end{array}$ & $\begin{array}{c}\text { Free } \\
\text { iodine } \\
\text { thyroxine } \\
\text { concen- } \\
\text { tration }\end{array}$ \\
\hline Thyrotoxicosis & $0.104 \pm 0.026$ & $13.08 \pm 3.42$ & $25.7 \times 10^{-11}$ \\
Normal & $0.046 \pm 0.005$ & $2.76 \pm 0.50$ & $5.4 \times 10^{-11}$ \\
Hypothyroidism & $\mathbf{0 . 0 2 8} \pm 0.008$ & $0.38 \pm 0.08$ & $0.8 \times 10^{-11}$ \\
Pregnancy & $\mathbf{0 . 0 2 6} \pm 0.004$ & $2.35 \pm 0.70$ & $4.6 \times 10^{-11}$ \\
Euthyroid "sick" & $0.088 \pm 0.036$ & $4.76 \pm 2.62$ & $9.4 \times 10^{-11}$ \\
\hline
\end{tabular}

* Mean values \pm standard deviations are given in the first two columns.

low per cent free thyroxine but a high PBI. Despite marked overlap with the normal range, the mean value for free thyroxine iodine in pregnancy was significantly reduced $(0.01<\mathrm{p}<0.02)$. This finding is in agreement with our previous report (1) as well as with the inference of Robbins and Nelson (17), who calculated a small but significant diminution in the mean free thyroxine concentration in pregnancy, based upon computations from electrophoretic data with the aid of certain assumptions.

The thyrotoxic and hypothyroid groups had highly significant differences $(p<0.001)$ from the normal group, both with respect to per cent of free thyroxine and the computed free thyroxine iodine in millimicrograms per $100 \mathrm{ml}$.

The series of euthyroid sick patients showed elevations with a wide scatter.

The values of Figures 3 and 4 are presented with calculated mean molar concentrations in Table II.

The effect of abnormally low thyroxine-binding alpha-globulin. As expected, euthyroid individuals with low thyroxine-binding alpha-globulin (TBG)

TABLE III

Data illustrating determinations on control sera and sera with diminished thyroxine-binding alpha-globulin (TBG)

\begin{tabular}{lc}
\hline \multicolumn{1}{c}{ Sample } & \\
\hline & $\%$ \\
& 0.064 \\
Serum pool & 0.058 \\
0.057 & \\
& 0.044 \\
Individual normal serum (A.S.) & 0.335 \\
"Artificial toxic" (serum pool enriched & 0.091 \\
with thyroxine, 500 $\mu$ g/100 ml) & 0.024 \\
Thyrotoxicosis (T.B., no. 339) & 0.104 \\
Pregnancy (H.W., no. 56) & 0.110 \\
Low serum TBG (A.L., no. 434) & 0.100 \\
Low serum TBG (G.S., no. 309) & \\
\hline
\end{tabular}

exhibited an abnormally high per cent free thyroxine. Because of low PBI values, the products representing free thyroxine iodine were approximately in the normal range.

The results in a typical study are depicted in Table III. Triplicate determinations on a serum pool were run as a standard, as well as a known high value (untreated thyrotoxicosis) and a known low value (pregnancy). It should be noted that the individual normal serum had a lower value than the serum pool from a clinical laboratory; this was believed to be due to the nonspecific effects of severe illness (vide infra).

An "artificial toxic" serum was regularly run, i.e., a serum pool enriched with $500 \mu \mathrm{g}$ per $100 \mathrm{ml}$ nonradioactive thyroxine, to provide a known high value.

\section{Discussion}

The fraction of unbound thyroxine and the computed free thyroxine iodine concentration in serum have been found to be elevated above normal in thyrotoxicosis and reduced in hypothyroidism. However, the free thyroxine iodine values $e x-$ hibited much more pronounced deviations from normal.

The calculated absolute free hormone concentration was better correlated with thyroid function than the PBI. This is well illustrated in the euthyroid pregnant subjects with the characteristic elevation of PBI attributable to increased TBG concentration $(1,17-24)$, but a low per cent free thyroxine, giving a computed free thyroxine iodine concentration in the low normal range. It is considered likely that the physiological activity of thyroxine depends upon the concentration of unbound hormone.

The uptake of unbound thyroxine by rat diaphragms has been studied as a model for tissue uptake in vivo in work to be reported separately $(25,26)$. Rat hemidiaphragms were placed in the buffer outside dialysis bags containing serum to which thyroxine-181I had been added. The two halves of the diaphragm were run against a normal control serum and an abnormal serum. After a 16-hour period of shaking in the $37^{\circ} \mathrm{C}$ water bath, the diaphragms were blotted and placed in counting tubes for radioactive assay of the two halves. Despite the presence of preponderant contaminating radioactive iodide in dialyzates, which 
might be expected to minimize differences, markedly elevated radioactivity was observed in hemidiaphragms run against the sera of thyrotoxic subjects in comparison to those run against normal sera, and diminished radioactivity was observed in hemidiaphragms run against sera of myxedematous subjects in comparison to normal sera. The differences observed in the model system studied were considered confirmatory of the physiologic role of unbound thyroxine (26).

Throughout this and previous discussions by the present author and others, the terms "free" and "unbound" thyroxine have been used interchangably to refer to the minute diffusible moiety of hormone. During the course of the present investigation, a report has appeared concerning a "dialyzable thyroid hormone binding material" in human serum, by Hoch, Sinnett, Miller, and Mahady (27). These workers obtained a material by methanolic ammonia extraction of freeze-dried dialyzate. The material in the extract seemed to interact with thyroxine and triiodothyronine, as evidenced by an altered $R_{f}$ value on paper chromatography, as well as a decreased coefficient of escape of the hormones through cellophane. If the findings of Hoch and co-workers are corroborated, it would appear preferable to regard the thyroxine in dialyzates and ultrafiltrates as "nonprotein bound," "diffusible," or "dialyzable" hormone, since it may not be present in solution as a free anion, but could be partly bound by a diffusible small molecule: Such a concept is by no means unreasonable in light of present information concerning thyroxine interactions. Pending further clarification of the physical chemical state of thyroxine in dialyzates, the so-called "free" thyroxine should be understood to indicate the nonprotein bound moiety.

The free thyroxine values of the present study are considerably lower than those previously reported from this laboratory (1). In retrospect, it appears probable that the column fractionation may have failed to remove a small amount of radioactive iodide, resulting in systematically elevated figures. The close agreement between samples of the same dialyzate run by magnesium precipitation and by the resin dialysis procedure (11-13) affords support for the validity of the present values. The agreement with the results of ultrafiltration provides further corroboration.
The present range of values is higher than those reported by Lee, Henry, and Golub, who employed gel filtration (28). Lee's normal mean value of $3.1 \mathrm{~m} \mu \mathrm{g}$ of thyroxine per $100 \mathrm{ml}$ corresponds to $2.0 \mathrm{~m} \mu \mathrm{g}$ of thyroxine iodine per $100 \mathrm{ml}$, which should be compared with the present figure of 2.76. However, the gel filtration procedure was not advocated as a regular routine method. In subsequent extensive studies (29), Lee has obtained essentially the same findings with the magnesium precipitation method as presently reported. Lee prefers TechniLab ${ }^{16}$ cells for the dialysis rather than the bags and tubes utilized in the present work. In our hands TechniLab cells and Visking casing in cellulose nitrate tubes yielded the same results.

Oppenheimer and co-workers $(16,30,31)$ used a diluted system, followed by addition of proteins to the dialyzate and trichloroacetic acid precipitation; their mean normal free thyroxine value of $3.02 \times$ $10^{-11}$ mole per $\mathrm{L}$ should be compared with the present mean of $5.4 \times 10^{-11}$ mole per $\mathrm{L}$. The difference is ascribed to Oppenheimer's use of a diluted system, which has been found to give diminished values.

The effect of dilution of serum with phosphate buffer is to raise the unbound thyroxine fraction (1), and Oppenheimer and Surks have assumed that the elevation is directly proportional to the dilution (16). This assumption of a linear effect of dilution is supported by a mathematical analysis, and by determinations in sera diluted $1: 8,1: 30$, and $1: 150$, which were not, however, compared with values from undiluted sera. Nevertheless, these authors did report measurements on ultrafiltrates of undiluted sera. These figures were, in fact, appreciably higher than the above-mentioned findings on diluted sera; they interpreted these higher values on undiluted sera as due to inaccuracies of the ultrafiltration procedure.

In contrast, the findings of Ingbar and associates $(12,13)$ illustrate graphically that where diluted sera (1:5 to $1: 300)$ were employed, and the unbound thyroxine fraction was divided by the appropriate dilution factor, the value obtained was approximately half that of undiluted sera. Consequently, Ingbar has regarded the values from diluted sera as "spuriously low" $(12,13)$.

\footnotetext{
16 Dialysis cell, model E-5, TechniLab Instruments, Los Angeles, Calif.
} 
These findings of approximately half the expected values have been verified by the present workers with sera diluted $1: 10,1: 25,1: 50$, $1: 100,1: 150$, and $1: 300$. Similar results have been obtained by Hollander (32) and by Lee, who has carried out extensive studies (29). It is, therefore, quite clear that dilution of serum with phosphate buffer results in a rise in unbound thyroxine fraction only about half as great as might be anticipated a priori. The possibility of multiplying the values obtained with diluted sera by an empirical constant is under study.

The explanation for this phenomenon is not at hand, but it may well reflect factors other than simple equilibria between thyroxine and serum protein carriers. One hypothesis that merits consideration is the possible interaction of thyroxine with the dialyzable substance reported by Hoch and co-workers (27) and referred to above. Dilution of serum with phosphate buffer could conceivably result in reduction of this material to negligible amounts, with consequent reduction of diffusible thyroxine.

Studies in this laboratory to be reported elsewhere (25) have employed ultrafiltrates as a diluent of sera before dialysis, which was then carried out against ultrafiltrate. Dilution of serum with ultrafiltrate rather than phosphate buffer has avoided the above-mentioned phenomenon of a fall in apparent unbound thyroxine fraction after correction for the dilution factor. When ultrafiltrate was used as a diluent and dialyzate, the corrected values were not depressed. This finding would also seem compatible with the existence of a dialyzable and ultrafiltrable substance that binds thyroxine.

As indicated in Figure 1, the resin dialysis method of Ingbar and co-workers (11-13) gave values in close agreement with those of the magnesium precipitation method when run on samples of the same dialyzates. The magnesium procedure was preferred because of greater speed, and because the direct recovery of thyroxine radioactivity in the dialyzate permitted higher counting rates.

The increment in thyroxine concentration due to added tracer was $3 \mu \mathrm{g}$ per $100 \mathrm{ml}$ or less, equivalent to PBI increments of not more than $2 \mu \mathrm{g}$ per $100 \mathrm{ml}$. The observation that such increments had no detectable effect was important in view of the finding of slight but definite elevations of the free thyroxine by increments as small as 5 to $8 \mu \mathrm{g}$ of thyroxine per $100 \mathrm{ml}$, values well below the reported maximal binding capacity of the thyroxinebinding alpha-globulin, usually estimated as 20 to $25 \mu \mathrm{g}$ thyroxine per $100 \mathrm{ml}$ in loading studies (24, $30,33-39)$. Whereas increments not producing saturation of TBG may theoretically increase free thyroxine, it seems reasonable at this stage to mention the possibility that the "TBG binding capacity" may represent the summation of the binding capacities of two alpha-globulins not separated readily by conventional paper electrophoresis. Suggestions of an additional protein carrier have been provided by our findings of two apparently distinct alpha-globulins on DEAE-Sephadex gel filtration of Fraction IV-4 as well as by an additional protein on immunoelectrophoresis (40) and starch gel electrophoresis $(41,42)$.

The computed normal mean value for free thyroxine iodine was $2.76 \mathrm{~m} \mu \mathrm{g}$ per $100 \mathrm{ml}$, which corresponds to a concentration of $5.4 \times 10^{-11}$ mole per $\mathrm{L}$ (Table II). Such a value is in agreement with the original computations of Robbins and Rall (33, 35) based upon electrophoretic determination of the amount of thyroxine in serum bound by albumin together with the binding constants for the interaction between thyroxine and bovine serum albumin. The calculation is corroborated by more recent determinations of these binding constants for human serum albumin (9).

It is noteworthy that the euthyroid sick group in the present study showed appreciable elevations above normal in both per cent and calculated absolute values for free thyroxine. These patients were extremely ill, in some instances moribund, in contrast to the previously reported group without significant elevations, which consisted mainly of ambulatory patients with minor illnesses (1). Diminished total binding capacity of prealbumin (TBPA) in various nonthyroidal illnesses has been reported by Ingbar and associates $(34,36$, $43)$ and by Oppenheimer and co-workers $(30,31)$. In addition to diminished binding capacity, Oppenheimer and associates showed disappearance of stainable prealbumin-1 on starch gel electrophoresis and a rise in free thyroxine.

Further work will be required to elucidate the significance of elevated free thyroxine concentrations in severely ill patients without stigmata of 
thyrotoxicosis, as well as the anomalies in liver disease. It is worth recalling that several years ago accelerated thyroxine turnover and removal rates were observed in nonendocrine hypermetabolism (for example, acute leukemia) with normal PBI concentration (44). Such observations suggested that possible differences in peripheral tissue metabolism, or some function thereof, had importance in determining the daily removal rate of hormone. Moreover, the slow radioactive thyroxine turnover curves of myxedematous patients were changed only by relatively prolonged replacement therapy; large intravenous injections of thyroxine as great as $2 \mathrm{mg}$ produced no evident alterations $(44,45)$ in disappearance curves. The subsequent "loading" experiments with intravenous doses of $4 \mathrm{mg}$ of thyroxine described by Ingbar and Freinkel (34) demonstrated increased hepatic radioactivity on external counting, as well as an abrupt but transitory fall in the plasma thyroxine radioactivity. Even when converted rapidly to the euthyroid state with triiodothyronine, the myxedematous subjects who had received 1 to $2 \mathrm{mg}$ thyroxine intravenously exhibited constancy of the disappearance curve over the course of several weeks (45). This signified an unaltered daily fractional turnover despite the increased absolute removal rate entailed by elevation of the PBI concentration by as much as $20 \mu \mathrm{g}$ per $100 \mathrm{ml}$. Such elevations, which may be presumed to have raised the free thyroxine concentration markedly, did not significantly alter disappearance curves, which changed toward normal only after months of replacement therapy (45). It may therefore be inferred that rate-limiting processes in hepatic and peripheral tissues may have importance in determining fractional turnover regardless of the level of free thyroxine and the absolute removal rate.

Further studies correlating free thyroxine concentration with radioactive thyroxine turnover data may provide a more complete picture. The free thyroxine of serum is believed, at present, to be an important determinant of the removal rate, as well as the probable form in which the hormone enters the tissues to exert its physiological effects.

\section{Summary}

1) A simplified method has been developed for the measurement of unbound thyroxine in serum.
2) Serum was dialyzed after addition of tracer ${ }^{131}$ I-labeled thyroxine. The dialyzate was enriched with nonradioactive thyroxine followed by precipitation with magnesium. The washed precipitate contained virtually all the dialyzed tracer thyroxine freed of contaminating iodide.

3) The free thyroxine fraction represented the thyroxine radioactivity in the dialyzate divided by thyroxine radioactivity in the original undialyzed serum.

4) The mean free thyroxine was $0.046 \%$ of the total thyroxine of normal serum, corresponding to a concentration of $5.4 \times 10^{-11}$ mole per $\mathrm{L}$.

5) The observed free thyroxine values, expressed as per cent of the total thyroxine content of the sera, were as follows (mean \pm standard deviation) : thyrotoxicosis, $0.104 \pm 0.026$; euthyroidism, $0.046 \pm 0.005$; hypothyroidism, $0.028 \pm$ 0.008 ; pregnancy, $0.026 \pm 0.004$; and euthyroid "sick" group, $0.088 \pm 0.036$.

6) The product of the per cent free thyroxine and the protein-bound iodine gave a value for free thyroxine iodine concentration that showed marked deviation from normal in thyrotoxicosis and hypothyroidism. This value appeared to be more closely correlated with thyroid function than the total hormone concentration.

7) The findings are compatible with the concept that the physiological activity of thyroxine depends upon the concentration of unbound hormone.

\section{Acknowledgments}

We wish to express gratitude for the valuable technical assistance of Mrs. Estera Gropper and Mr. Alexander Bryant, and to the physicians who provided blood sera: Drs. Solomon A. Berson, David V. Becker, Solomon Silver, A. Stone Freedberg, and Samuel P. Asper, Jr.

\section{References}

1. Sterling, K., and A. Hegedus. Measurement of free thyroxine concentration in human serum. J. clin. Invest. 1962, 41, 1031.

2. Kendall, E. C., and A. E. Osterberg. The chemical identification of thyroxine. J. biol. Chem. 1919, 40, 265.

3. Kendall, E. C. Thyroxine. New York, Chemical Catalog Company, 1929.

4. Lardy, H. Effect of thyroid hormones on enzyme systems in The Thyroid, Brookhaven Symposia in Biology, 1955, no. 7, p. 94.

5. Sterling, K., and M. Tabachnick. Determination of the binding constants for the interaction of thyrox- 
ine and its analogues with human serum albumin. J. biol. Chem. 1961, 236, 2241.

6. Sterling, K., P. Rosen, and M. Tabachnick. Equilibrium dialysis studies of the binding of thyroxine by human serum albumin. J. clin. Invest. 1962, 41, 1021.

7. Sterling, K., and M. Tabachnick. Paper electrophoretic demonstration of thyroxine binding prealbumin fraction in serum. Endocrinology 1961, 68, 1073.

8. Berson, S. A., R. S. Yalow, J. Sorrentino, and B. Roswit. The determination of thyroidal and renal plasma $I^{191}$ clearance rates as a routine diagnostic test of thyroid dysfunction. J. clin. Invest. 1952, 31, 141.

9. Sterling, K. Molecular structure of thyroxine in relation to its binding by human serum albumin. J. clin. Invest. 1964, 43, 1721.

10. Walser, M. Ion Association. VI. Interactions between calcium, magnesium, inorganic phosphate, citrate and protein in normal human plasma. J. clin. Invest. 1961, 40, 723.

11. Ingbar, S. H., L. E. Braverman, N. Dawber, and G. Y. Lee. A simple method for measuring the free thyroid hormone in serum (abstract). Clin. Res. 1964, 12, 271.

12. Ingbar, S. H. Personal communication.

13. Ingbar, S. H., L. E. Braverman, N. A. Dawber, and G. Y. Lee. A new method for measuring the free thyroid hormone in human serum and an analysis of the factors that influence its concentration. J. clin. Invest. 1965, 44, 1679.

14. Sterling, K., A. Hegedus, and T. S. Walker. Unpublished observations.

15. Toribara, T. Y., A. R. Terepka, and P. A. Dewey. The ultrafiltrable calcium of human serum. I. Ultrafiltration methods and normal values. J. clin. Invest. 1957, 36, 738.

16. Oppenheimer, J. H., and M. I. Surks. Determination of free thyroxine in human serum: a theoretical and experimental analysis. J. clin. Endrocr. 1964, 24, 785.

17. Robbins, J., and J. H. Nelson. Thyroxine-binding by serum protein in pregnancy and in the newborn. J. clin. Invest. 1958, 37, 153.

18. Dowling, J. T., N. Freinkel, and S. H. Ingbar. Thyroxine-binding by sera of pregnant women. J. clin. Endocr. 1956, 16, 280.

19. Dowling, J. T., N. Freinkel, and S. H. Ingbar. Effect of diethylstilbestrol on the binding of thyroxine in serum. J. clin. Endocr. 1956, 16, 1491.

20. Dowling, J. T., N. Freinkel, and S. H. Ingbar. Thyroxine-binding by sera of pregnant women, newborn infants, and women with spontaneous abortion. J. clin. Invest. 1956, 35, 1263.

21. Dowling, J. T., N. Freinkel, and S. H. Ingbar. Iodine metabolism in hydatidiform mole and choriocarcinoma. J. clin. Endocr. 1960, 20, 1.
22. Engbring, N. H., and W. W. Engstrom. Effects of estrogen and testosterone on circulating thyroid hormone. J. clin. Endocr. 1959, 19, 783.

23. Nicoloff, J. T., R. Nicoloff, and J. T. Dowling. Evaluation of vaginal smear, serum gonadotropin, protein-bound iodine, and thyroxine-binding as measures of placental adequacy. J. clin. Invest. 1962, 41, 1998.

24. Sterling, K. Thyroxine in blood. Proc. Mayo Clin. 1964, 39, 586.

25. Sterling, K. Unpublished observations.

26. Sterling, K., and M. A. Brenner. Rat diaphragm uptake of free thyroxine (abstract). The Endocrine Society Annual Meeting, New York, N. Y., June 17-19, 1965.

27. Hoch, H., S. L. Sinnett, P. O. Miller, and I. B. Mahady. Dialyzable thyroid hormone-binding material in human serum. Biochemistry 1965, 4, 931.

28. Lee, N. D., R. J. Henry, and O. J. Golub. Determination of the free thyroxine content of serum. $\mathrm{J}$. clin. Endocr. 1964, 24, 486.

29. Lee, N. D. Personal communication.

30. Oppenheimer, J. H., R. Squef, M. I. Surks, and H. Hauer. Binding of thyroxine by serum proteins evaluated by equilibrium dialysis and electrophoretic techniques. Alterations in non-thyroidal illness. J. clin. Invest. 1963, 42, 1769.

31. Surks, M. I., and J. H. Oppenheimer. Postoperative changes in the concentration of thyroxine-binding prealbumin and serum free thyroxine. J. clin. Endocr. 1964, 24, 794.

32. Hollander, C. S. Personal communication.

33. Robbins, J., and J. E. Rall. The interaction of thyroid hormones and protein in biological fluids. Recent Progr. Hormone Res. 1957, 13, 161.

34. Ingbar, S. H., and N. Freinkel. Regulation of the peripheral metabolism of the thyroid hormones. Recent Progr. Hormone Res. 1960, 16, 353.

35. Robbins, J., and J. E. Rall. Proteins associated with the thyroid hormones. Physiol. Rev. 1960, 40, 415.

36. Ingbar, S. H., and N. Freinkel. Thyroid hormones in Hormones in human plasma : Nature and Transport, H. N. Antoniades, Ed. Boston, Little, Brown, 1960 , p. 515.

37. Balfour, W. E., and H. E. Tunnicliffe. Thyroxine binding by serum proteins. J. Physiol. (Lond.) 1960, 153, 179.

38. Myant, N. B., and C. Osorio. Paper electrophoresis of thyroxine in tris-maleate buffer. J. Physiol. (Lond.) 1960, 152, 601.

39. Ingbar, S. H., C. Waterhouse, and P. Cushman. Observations on the nature of the underlying disorder and the occurrence of associated plasma transport abnormalities in a patient with an idiopathic increase in the plasma thyroxine-binding globulin. J. clin. Invest. 1964, 43, 2266.

40. Christian, C. L., and R. W. Lightfoot, Jr. Personal communication. 
41. Blumberg, B. S., L. Farer, J. E. Rall, and J. Robbins. Thyroxine-serum protein complexes: two-dimension gel and paper electrophoresis studies. Endocrinology 1961, 68, 25.

42. Inada, M., and K. Sterling. Probable demonstration of more than a single thyroxine binding alphaglobulin (TBG) on starch gel electrophoresis (abstract). Clin. Res. 1965, 13, 532.

43. Richards, J. B., J. T. Dowling, and S. H. Ingbar. Alterations in the plasma transport of thyroxine in sick patients and their relation to the abnormality in Graves' disease (abstract). J. clin. Invest. 1959, 38, 1035.

44. Sterling, K., and R. B. Chodos. Radiothyroxine turnover studies in myxedema, thyrotoxicosis, and hypermetabolism without endocrine disease. J. clin. Invest. 1956, 35, 806.

45. Sterling, K. Radiothyroxine turnover studies in thyroid disease after therapy. J. clin. Invest. 1958, 37, 1348. 